\title{
UDC 517.919
}

\section{PERIODIC SOLUTIONS OF LINEAR SYSTEMS WITH ASYMMETRIC VARIABLE RANK MATRIX IN THE DERIVATIVES}

\author{
Valerii Yeromenko; Andrii Aliluiko
}

\author{
Ternopil National Economic University, Ternopil, Ukraine
}

\begin{abstract}
Summary. The effective sufficient conditions for a positive definite symmetrization of a differential operator based on a system of two linear first order ordinary differential equations with an asymmetric variable rank matrix in the derivatives were established. According to these conditions, the existence of a periodic solution for the arbitrary periodic inhomogeneity and the Galerkin iterative method of its approximate construction was confirmed. The approach for the research of $n$ numbers of the equations, where $n>2$, was described.
\end{abstract}

Key words: degenerate systems of linear differential equations, periodic solutions.

https://doi.org/10.33108/visnyk_tntu2019.04.112

Received 02.01.2020

Statement of the problem. There happen to be processes in different branches of modern science and engineering being modeled by the linear systems of usual differential equations with a degenerate matrix in derivatives. Such systems appear in the theory of automatic control, mathematic economics, kinetics, theory of non-linear vibrations, theory of gyroscopic systems, etc. The problem on the periodic or quasi-periodic solutions of such systems has not been studied good enough.

Analysis of the results of investigation. The systems of equations of the type

$$
A(t) x^{(1)}+B(t) x=f(t),
$$

where $x \in R^{n}, x^{(1)}=d x / d t, A$ and $B$ - are quadratic matrixes,

$$
\operatorname{rang} A(t) \equiv \text { const }<n \forall t \in[0, T] \text {, }
$$

which are the most profound studied in [1]. The problem on periodic solutions was studied in [2] for the positive symmetric systems of differential equations, for which the condition (2) can not be provided. The results of investigation of conditions for quasi-periodic solutions of the system for the arbitrary periodic inhomogeneity are presented in [3] having assumed, that $\operatorname{rang} A(t) \leq 1$. In [4] there have been obtained the conditions for invariant manifold in the linear systems with the variable rank matrix in the derivatives for the cases, when this matrix is diagonal or has a rank being not more than 1. In papers [5] and [6] the linear systems, in which the matrix rank in the derivatives changes from $n-1$ till $n$, were investigated. As far as we know, the system (1) has not been studied enough even for $n=2$ in the case $\operatorname{rang} A(t) \in[0 ; 2]$.

The objective. To investigate the efficient conditions of the single periodic solution for the arbitrary periodic inhomogeneity for the system (1) with periodic coefficients, where $x \in R^{2}, A(t)$ - is asymmetric matrix, $\operatorname{rang} A(t) \in[0 ; 2]$ and to present the approach to the study of the case of $n>2$ equations.

Statement of the task. Let us analyze the system of two equations 


$$
\alpha(t) A_{1}(t) x^{(1)}+B(t) x=f(t)
$$

where $x \in R^{2}, \alpha(t)$ - is the scalar function, which can be of zero value, $A_{1}^{*}(t) \neq A_{1}(t)$, rang $A_{1}(t) \in[1 ; 2], \alpha, A_{1}, B, f \in C^{r}\left(T_{1}\right)$, the asterisk signs the transpose operation of matrix; $C^{r}\left(T_{1}\right)$-is the space of vector or matrix functions being of real values, periodical with the $2 \pi$ period and those having stability derivative including up to the $r$ order. The problem on the single periodic solution for the arbitrary inhomogeneity $f(t)$ is being studied. The obligatory condition for such solution is nondegenerate matrix $B(t)$ [4]. Let us present the system (3) as follows:

$$
\alpha(t) a(t) x^{(1)}+x=g(t)
$$

where

$$
a=B^{-1} A_{1}, g=B^{-1} f .
$$

The idea of investigation the system (4) deals with building of so-called left symmetrizitor [7] $V(t)=\left\{v_{i j}\right\}_{i, j=1,2} \in C^{r}\left(T_{1}\right)$ of the matrix $B^{-1} A_{1}$, when for all $t \in T_{1}$

$$
\operatorname{det} V(t) \neq 0,\left(V(t) B^{-1}(t) A_{1}(t)\right)^{*}=V(t) B^{-1}(t) A_{1}(t)
$$

Then in the case, when the positively definite matrix $V(t)$, the system is similar to that of (4) and is positively determined symmetric system.

The elements of matrix $V(t)$ according to the second equation (6) must satisfy the relation

$$
\left\langle\left(a_{12}, a_{22},-a_{11},-a_{21}\right), v\right\rangle=0 \quad \forall t \in T_{1},
$$

where $\langle\cdot, \cdot\rangle-$ is the scalar derivative, $B^{-1} A_{1}=\left\{a_{i j}\right\}$,

$$
v=\left(v_{11}, v_{12}, v_{21}, v_{22}\right)
$$

here

$$
\beta=\sum_{i, j=1}^{2} a_{i j}^{2}>0 \quad \forall t \in T_{1}
$$

as $\operatorname{rang} B^{-1} A_{1} \geq 1$. The general solution of the equation (7) looks like [7]:

$$
v(t)=\sum_{i=1}^{3} \lambda_{i}(t) v_{i}(t),
$$

where

$$
v_{1}=\left(a_{21}, a_{11}, a_{22}, a_{12}\right), \quad v_{2}=\left(a_{22},-a_{12},-a_{21},-a_{11}\right), v_{3}=\left(-a_{11}, a_{21},-a_{12}, a_{22}\right),
$$

$\lambda_{i}(t), i=\overline{1,3},-$ are arbitrary real scalar functions, which are to be determined. 
Taking into account the relations (8), (10) and (11), we will obtain

$$
V(t)=\left(\begin{array}{ll}
\lambda_{1} a_{21}+\lambda_{2} a_{22}-\lambda_{3} a_{11} & \lambda_{1} a_{11}-\lambda_{2} a_{12}+\lambda_{3} a_{21} \\
\lambda_{1} a_{22}-\lambda_{2} a_{21}-\lambda_{3} a_{12} & \lambda_{1} a_{12}+\lambda_{2} a_{11}+\lambda_{3} a_{22}
\end{array}\right) .
$$

Let us choose the value of functions $\lambda_{i}(t), i=\overline{1,3}$ so, that $V(t) \in C^{r}\left(T_{1}\right)$ and

$$
\min _{\|\xi\|=1}\langle V(t) \xi, \xi\rangle=1 \quad \forall t \in T_{1} .
$$

For this let us analyze the system of equations

$$
\left\{\begin{array}{l}
v_{12}+v_{21}=0 \\
v_{11}=1 \\
v_{22}=1
\end{array}\right.
$$

that is,

$$
C\left(\begin{array}{l}
\lambda_{1} \\
\lambda_{2} \\
\lambda_{3}
\end{array}\right)=\left(\begin{array}{l}
0 \\
1 \\
1
\end{array}\right)
$$

where

$$
C=\left(\begin{array}{ccc}
a_{11}+a_{22} & -\left(a_{21}+a_{12}\right) & a_{21}-a_{12} \\
a_{21} & a_{22} & -a_{11} \\
a_{12} & a_{11} & a_{22}
\end{array}\right) .
$$

Let us analyze the conditions of system compatibility (14), taking into account, that

$$
\operatorname{det} C=\left(a_{11}+a_{22}\right) \beta \text {, }
$$

where $\beta$ is found (9).

If

$$
\operatorname{tr}\left(B^{-1} A_{1}\right)=a_{11}+a_{22} \neq 0 \quad \forall t \in T_{1},
$$

then according to (15) and (9) the matrix $C$ is nondegenerate matrix and the system of equations (14) has the single solution

$$
\begin{gathered}
\lambda_{1}=2\left(a_{11} a_{21}+a_{12} a_{22}\right)(\operatorname{det} C)^{-1}, \lambda_{2}=\left[\left(a_{11}+a_{22}\right)^{2}+\left(a_{12}-a_{21}\right)^{2}\right](\operatorname{det} C)^{-1}, \\
\lambda_{3}=\left(-a_{11}^{2}-a_{12}^{2}+a_{21}^{2}+a_{22}^{2}\right)(\operatorname{det} C)^{-1},
\end{gathered}
$$

basing on which we will obtain the matrix from (12)

$$
V(t)=\left(\begin{array}{cc}
1 & \left(a_{21}-a_{12}\right)\left(a_{11}+a_{22}\right)^{-1} \\
\left(a_{12}-a_{21}\right)\left(a_{11}+a_{22}\right)^{-1} & 1
\end{array}\right) .
$$


Let us assume, that the condition (16) is not satisfied in the isolated points and $t_{0}-$ is one of them. Then

$$
\begin{gathered}
a_{11}\left(t_{0}\right)+a_{22}\left(t_{0}\right)=0, \\
C\left(t_{0}\right)=\left(\begin{array}{ccc}
0 & -a_{12}-a_{21} & -a_{12}+a_{21} \\
a_{21} & -a_{11} & -a_{11} \\
a_{12} & a_{11} & -a_{11}
\end{array}\right),
\end{gathered}
$$

$\operatorname{rang} C\left(t_{0}\right)=2$, as the sum of squares of the second order minors of matrix $C\left(t_{0}\right)$ is equal to $2\left(a_{11}^{2}+a_{12}^{2}+a_{21}^{2}\right)\left(2 a_{11}^{2}+a_{12}^{2}+a_{21}^{2}\right)$, that is, it is different from that of zero according to (9) and expectation (18).

The equation $C^{*}\left(t_{0}\right) z=0$ has the solution

$$
z\left(t_{0}\right)=\left(a_{11}\left(t_{0}\right),-a_{12}\left(t_{0}\right), a_{21}\left(t_{0}\right)\right)^{*},\left\|z\left(t_{0}\right)\right\| \neq 0 .
$$

Then to make the companion system (14), it is necessary and enough to have

$$
\left\langle\left(\left(a_{11}\left(t_{0}\right),-a_{12}\left(t_{0}\right), a_{21}\left(t_{0}\right)\right),(0,1,1)\right\rangle=0,\right.
$$

that is,

$$
a_{12}\left(t_{0}\right)-a_{21}\left(t_{0}\right)=0
$$

Let us assume, that

$$
\frac{a_{12}(t)-a_{21}(t)}{a_{11}(t)+a_{22}(t)}=d(t) \in C^{r}\left(T_{1}\right)
$$

The matrix $\tilde{C}$, connected to the matrix $C$, looks like

$$
\tilde{C}=\left(\begin{array}{ccc}
a_{11}^{2}+a_{22}^{2} & -2 a_{11} a_{12} & 2 a_{11} a_{21} \\
a_{11}\left(a_{21}-a_{12}\right) & -a_{12}\left(a_{21}-a_{12}\right) & a_{21}\left(a_{21}-a_{12}\right) \\
a_{11}\left(a_{12}+a_{21}\right) & -a_{12}\left(a_{12}+a_{21}\right) & a_{21}\left(a_{12}+a_{21}\right)
\end{array}\right),
$$

that is why, taking into account (15) and (20)

$$
\begin{gathered}
\tilde{C} C=\left(a_{11}+a_{22}\right) \beta I_{3}, \\
\tilde{C}\left(\begin{array}{l}
0 \\
1 \\
1
\end{array}\right)=\left(\begin{array}{c}
2\left(a_{11} a_{21}+a_{12} a_{22}\right) \\
\left(a_{11}+a_{22}\right)^{2}+\left(a_{12}-a_{21}\right)^{2} \\
a_{22}^{2}-a_{11}^{2}+a_{21}^{2}-a_{12}^{2}
\end{array}\right)=\left(\begin{array}{c}
2\left(a_{12}-a_{11} d\right) \\
a_{11}+a_{22}+\left(a_{12}-a_{21}\right) d \\
a_{22}-a_{11}-\left(a_{12}+a_{21}\right) d
\end{array}\right)\left(a_{11}+a_{22}\right),
\end{gathered}
$$

where $I_{3}-$ is the unit matrix of the third order. That is, the solution of the system (14) in this case looks like: 


$$
\lambda_{1}=2\left(a_{12}-a_{11} d\right) \beta^{-1}, \lambda_{2}=\left[a_{11}+a_{22}+\left(a_{12}-a_{21}\right) d\right] \beta^{-1}, \lambda_{3}=\left[a_{22}-a_{11}-\left(a_{12}+a_{21}\right) d\right] \beta^{-1},
$$

where $d(t)$ is found (20). Having substituted the obtained data in (12), we will obtain the necessary matrix.

$$
V(t)=\left(\begin{array}{cc}
1 & -d(t) \\
d(t) & 1
\end{array}\right)
$$

which, taking into account (20), is similar to that of (17). Here it is considered, that according to the relations (7)-(12), the matrix $V(t)$ is found within the scalar multiplier, which is different from that of zero.

If $\operatorname{tr}\left[B^{-1}(t) A_{1}(t)\right] \equiv 0$, and there is at least one point $t$, in which $a_{12}(t) \neq a_{21}(t)$ then the system (14) is not compatible, that is, it is not possible to make the symmetrization of the system being of positively defined.

In conclusion, we will obtain the following statement.

Lemma. Let such conditions be satisfied for the system of two equations (3):

1) $\alpha, A_{1}, B, f \in C^{r}\left(T_{1}\right), \operatorname{rang} A_{1} \geq 1, \operatorname{det} B(t) \neq 0 \forall t \in T_{1}$;

2) $\left(a_{12}-a_{21}\right)\left(a_{11}+a_{22}\right)^{-1} \in C^{r}\left(T_{1}\right)$, where $B^{-1} A_{1}=\left\{a_{i j}\right\}$.

Then the system (3) is equivalent to the system

$$
L x \equiv \alpha(t) V(t) B^{-1}(t) A_{1}(t) x^{(1)}+V(t) x=V(t) B^{-1}(t) f(t),
$$

where for all $t \in T_{1}$

$$
\left(V B^{-1} A_{1}\right)^{*} \equiv V B^{-1} A_{1}, \min _{\|\xi\|=1}\langle V(t) \xi, \xi\rangle=1,
$$

the matrix $V(t) \in C^{r}\left(T_{1}\right)$ is determined (17).

According to (23) the equations system (22) is the positively definite symmetric system. If $|\alpha(t)|$ is small enough, then for every integer $s=0,1, \ldots, r$ and $t \in T_{1}$ the inequality is provided

$$
\min _{\|\xi\|=1}\left\langle\left[1+\left(s-\frac{1}{2}\right)\left(\alpha V B^{-1} A_{1}\right)^{(1)}\right] \xi, \xi\right\rangle \geq \gamma, \gamma=\text { const }>0,
$$

which quarantees [8] for performing the priori estimation of the operator $L$, as well as the single solution $x_{0}(t) \in C^{k}\left(T_{1}\right), k \geq 1$ being available of the system (22), thus, of the system (3) for the arbitrary inhomogeneity, if $r \geq k+1$.

Let us make the main statement.

Theorem. Let the conditions of lemma be provided for the equations system (3), where $r \geq k+1, k \geq 1$, as well as inequality (24), where $s=\overline{0, r}$.

Then the system (3) has the single solution $x_{0}(t) \in C^{k}\left(T_{1}\right)$ for any inhomogeneity $f(t)$

Note. In the paper [7] it was shown, that while building the approximation to $x_{0}(t)$, when their compatability is proved according to the Galyorkin iteration method [8], the system (3) itself can be used instead of the system (22).

As an example let us analyze the system of the type (3): 


$$
p \sin t\left(\begin{array}{cc}
2 \cos ^{2} t & \sin t \\
\sin t & 2 \cos 2 t
\end{array}\right)\left(\begin{array}{l}
x_{1}^{(1)} \\
x_{2}^{(1)}
\end{array}\right)+\left(\begin{array}{ll}
0 & 1 \\
1 & 0
\end{array}\right)\left(\begin{array}{l}
x_{1} \\
x_{2}
\end{array}\right)=\left(\begin{array}{l}
f_{1}(t) \\
f_{2}(t)
\end{array}\right),
$$

where $p$-is positive parameter, $f_{1}, f_{2} \in C^{r}\left(T_{1}\right), r \geq 2$.

Let us find that value of parameter from the conditions of theorem, when the system (25) has a smooth periodic solution for any vector of homogeneity.

It should be noted, that the results of work [7] being inconstructive, it results in difficulties in the positively determined symmetrization of the system in question.

The system (25) is the equivalent to the system

$$
p \sin t\left(\begin{array}{cc}
\sin t & 2 \cos 2 t \\
2 \cos ^{2} t & \sin t
\end{array}\right)\left(\begin{array}{l}
x_{1}^{(1)} \\
x_{2}^{(1)}
\end{array}\right)+\left(\begin{array}{l}
x_{1} \\
x_{2}
\end{array}\right)=\left(\begin{array}{l}
f_{2}(t) \\
f_{1}(t)
\end{array}\right),
$$

for which $\left(a_{12}-a_{21}\right)\left(a_{11}+a_{22}\right)^{-1}=-\sin t$ and according to (17)

$$
V(t)=\left(\begin{array}{cc}
1 & \sin t \\
-\sin t & 1
\end{array}\right)
$$

Then

$$
\begin{gathered}
\alpha V B^{-1} A_{1}=p \sin t\left(\begin{array}{cc}
\left(1+2 \cos ^{2} t\right) \sin t & 2 \cos 2 t+\sin ^{2} t \\
2 \cos 2 t+\sin ^{2} t & (1-2 \cos 2 t) \sin t
\end{array}\right), \\
\left(\alpha V B^{-1} A_{1}\right)^{(1)}=p\left(\begin{array}{cc}
(1+2 \cos 2 t) \sin 2 t & \left(2 \cos 2 t-5 \sin ^{2} t\right) \cos t \\
\left(2 \cos 2 t-5 \sin ^{2} t\right) \cos t & \left(1+4 \sin ^{2} t-2 \cos 2 t\right) \sin 2 t
\end{array}\right),
\end{gathered}
$$

the eigenvalues of matrix $\left(\alpha V B^{-1} A_{1}\right)^{(1)}$

$$
\begin{aligned}
& \lambda_{\max }^{(t)}=p\left\{\left(1+2 \sin ^{2} t\right) \sin 2 t+\left[4\left(\cos 2 t-\sin ^{2} t\right)^{2} \sin ^{2} 2 t+\left(2 \cos 2 t-5 \sin ^{2} t\right)^{2} \cos ^{2} t\right]^{1 / 2}\right\} \\
& \lambda_{\min }^{(t)}=p\left\{\left(1+2 \sin ^{2} t\right) \sin 2 t-\left[4\left(\cos 2 t-\sin ^{2} t\right)^{2} \sin ^{2} 2 t+\left(2 \cos 2 t-5 \sin ^{2} t\right)^{2} \cos ^{2} t\right]^{1 / 2}\right\}
\end{aligned}
$$

using the MatLab system are assessed by the inequalities

$$
\max _{t \in T_{1}} \lambda_{\max }(t) \leq 5,39 p, \min _{t \in T_{1}} \lambda_{\min }(t) \geq-5,39 p
$$

The inequalities (24) are satisfied, if the parameter $p$ satisfies the inequality

$$
p \leq(1-\gamma) \min \left\{\frac{2}{5,39} ; \frac{1}{5,39 s}\right\}
$$

where $s=\overline{1, r}, \gamma$ is as small as possible positive number.

Conclusions. 1. Sufficient condition for realization of investigation for the system (3) presented in the paper are connections (20), that is, the algebraic equation solution being in the space $C^{r}\left(T_{1}\right)$ 


$$
\left(a_{11}+a_{22}\right) z=a_{12}-a_{21},
$$

where $a_{i j}-$ are the elements $B^{-1} A_{1}$. If this condition is not provided, then additional investigations are to be performed, beginning from the most simple case of the system type (3):

$$
\alpha(t)\left(\begin{array}{cc}
0 & a_{1}(t) \\
a_{2}(t) & 0
\end{array}\right) x^{(1)}+x=f(t),
$$

where $a_{1}(t) \neq a_{2}(t), \alpha(t)$ and $a_{1}(t) a_{2}(t)$ can be of zero value $a_{1}^{2}+a_{2}^{2}>0$

2. While generalizing the obtained results for the case of three equations of the system it should be noted, that the matrix $V(t)$ should be found as it follows:

$$
V=\left(\begin{array}{ccc}
1 & v_{1} & v_{2} \\
-v_{1} & 1 & v_{3} \\
-v_{2} & -v_{3} & 1
\end{array}\right),
$$

where unknown values $v_{1}, v_{2}, v_{3}$ are found as smooth periodic solution of the inhomogeneous system of three linear algebraic equations resulted by the matrix equation $\left(V B^{-1} A_{1}\right)^{*}=V B^{-1} A_{1}$. In general case the system of $\frac{n(n-1)}{2}$ numbers of equations must be investigated.

3. The results obtained in the paper can be used for studying the problem on periodic solutions of the system being available

$$
A(t) x^{\prime \prime}+B(t) x^{\prime}+C(t) x=f(t) .
$$

It was considered in [9], that $A(t)$ - is symmetric and $B(t)$ - is the matrix being positive or negative.

\section{References}

1. Samoilenko A. M., Shkil M. I., Yakovets V. P. Liniini systemy dyferentsialnykh rivnian $\mathrm{z}$ vyrodzhenniamy. Kyiv: Vyshcha shkola, 2000. 294 p. [In Ukrainian].

2. Mozer Yu. Bystrosxodyashhijsya metod iteracij i nelinejnye uravneniya. Uspexi mat. Nauk. Vol. 23. No. 4. 1968. P. 179-238. [In Russian].

3. Kulik V. L., Eremenko V. A. Quasiperiodic solutions of a linear system of differential equations with a singular matrix in the derivatives.Ukr. Mat. Zh. Vol. 32. No. 6. 1980. P. 502-508. https://doi.org/10.1007/ BF01087179

4. Simokon' V. Kh., Trokhimchuk E. P. On regularity of linear systems with a degenerate matrix by the derivative. Ukr. Mat. Zh. Vol. 45. No. 3. 1993. P. 299-308. https://doi.org/10.1007/BF01060987

5. Yeromenko V. O. Periodychni rozviazky funktsionalno-synhuliarno zburenykh liniinykh zvychainykh dyferentsialnykh rivnian vyshchykh poriadkiv, Matematychne ta kompiuterne modeliuvannia. Seriia: fizyko-matematychni nauky: zb. nauk. prats. Vol. 6. 2012. P. 97-113. [In Ukrainian].

6. Yeromenko V. O., Aliluiko A. M. Kvaziperiodychni rozviazky funktsionalno-synhuliarno zburenykh liniinykh zvychainykh dyferentsialnykh rivnian vyshchykh poriadkiv. Neliniini kolyvannia. Vol. 21. No. 4. 2018. P. 457-469. [In Ukrainian].

7. Eremenko V. A. Periodic solutions of systems of two linear first-order ordinary differential equations with degenerate asymmetric matrix with derivatives. Ukr. Mat. Zh. Vol. 50. No. 3. 1998. P. 400-407. https://doi.org/10.1007/BF02528805

8. Samojlenko A. M. E'lementy matematicheskoj teorii mnogochastotnyx kolebanij. Invariantnye tory, Moscva: Nauka, 1987. 304 p. [In Russian].

9. Er'omenko V. O., Aliluiko A. M. Periodic solutions of linear degenerate systems of ordinary differential equations of the second order. Nonlinear Oscill. Vol. 13. No. 3. 2011. P. 361-371. https://doi.org/10.1007/ s11072-011-0119-3 
Список використаної літератури

1. Самойленко А. М., Шкіль М. І., Яковець В. П. Лінійні системи диференціальних рівнянь 3 виродженнями. К.: Вища школа, 2000. 294 с.

2. Мозер Ю. Быстросходящийся метод итераций и нелинейные уравнения. Успехи мат. наук. 1968. № 4 (23). C. 179-238.

3. Kulik V. L., Eremenko V. A. Quasiperiodic solutions of a linear system of differential equations with a singular matrix in the derivatives. Ukr. Mat. Zh. 1980. № 6 (32). P. 502-508. https://doi.org/10.1007/ BF01087179

4. Simokon' V. Kh., Trokhimchuk E. P. On regularity of linear systems with a degenerate matrix by the derivative. Ukr. Mat. Zh. 1993. № 2 (45). P. 299-308. https://doi.org/10.1007/BF01060987

5. Єрьоменко В. О. Періодичні розв'язки функціонально-сингулярно збурених лінійних звичайних диференціальних рівнянь вищих порядків. Математичне та комп'ютерне моделювання. Серія: фізико-математичні науки: зб. наук. праць. 2012. Вип. 6. С. 97-113.

6. Єрьоменко В. О., Алілуйко А. М. Квазіперіодичні розв'язки функціонально-сингулярно збурених лінійних звичайних диференціальних рівнянь вищих порядків. Нелінійні коливання. 2018. № 4 (21). P. 457-469.

7. Eremenko V. A. Periodic solutions of systems of two linear first-order ordinary differential equations with degenerate asymmetric matrix with derivatives. Ukr. Mat. Zh. 1998. № 3 (50). P. 400-407. https://doi.org/10.1007/BF02528805

8. Самойленко А. М. Элементы математической теории многочастотных колебаний. Инвариантные торы. М.: Наука, 1987. 304 с.

9. Er'omenko V. O., Aliluiko A. M. Periodic solutions of linear degenerate systems of ordinary differential equations of the second order. Nonlinear Oscill. 2011. № 3 (13). P. 361-371. https://doi.org/10.1007/ s11072-011-0119-3

\title{
УДК 517.919
}

\section{ПРО ПЕРІОДИЧНІ РОЗВ’ЯЗКИ ЛІНІЙНИХ СИСТЕМ IЗ НЕСИМЕТРИЧНОЮ МАТРИЦЕЮ ЗМІННОГО РАНГУ ПРИ ПОХІДНИХ}

\author{
Валерій Єрьоменко; Андрій Алілуйко
}

\section{Тернопільський начіональний економічний університет, Тернопіль, Украӥна}

Резюме. В різних галузях сучасної науки і техніки зустрічаються процеси, які моделюються лінійними системами звичайних диференціальних рівнянь із вироджуваною матрицею при похідних. Систематичне вивчення таких систем розпочалося порівняно недавно, з початку 70-х років минулого століття. На цей час найбільш розвиненою $є$ теорія вироджених лінійних систем зі сталими коефіцієнтами. Що ж стосується теорії вироджених систем зі змінними коефіцієнтами, то ї̈ розвинуто значно меншою мірою. Найповніше досліджено випадок сталого рангу матриці при похідних. Теорія існування періодичних та квазіперіодичних розв'язків для змінного рангу матриці при похідних далека від завершення й розроблена для додатно визначених симетричних систем, а також у випадках, коли цей ранг змінюється від 0 до 1 або від $n-1$ до $n$. Досліджено достатні умови існування єдиного періодичного розв'язку системи двох лінійних диференціальних рівнянь із матрицею при похідних, ранг якої змінюється від 0 до 2, для довільної періодичної неоднорідності. Встановлено достатні умови виконання апріорних оиінок для диференціального оператора, породженого вихідною системою, на підставі яких можна побудувати з допомогою ітерачійного методу Гальоркіна наближення до шуканого періодичного розв'язку, а також їх збіжність. При цььому вимагається існування неперервних похідних другого порядку коефіцієнтів системи, щзо зумовлено методом, використаним для обтрунтування процесу Гальоркіна. Ця вимога є типовою для функиіональних методів математичної фізики. Як приклад, досліджено систему, яку не вдається вивчити розробленими раніше методами. Вказано підхід до узагальнення отриманих результатів для випадку систем більшого числа диференціальних рівнянь. На изьому шляху потрібно досліджувати існування гладких періодичних розв'язків систем алгебрайчних лінійних неоднорідних рівнянь. Отримані в роботі результати можуть бути використані при розв 'язуванні задачі про існування періодичних розв'язків лінійних систем диференціальних рівнянь вищих порядків, у яких матриця при стариій похідній є несиметричною й виродженою.

Ключові слова: вироджувані системи лінійних диференціальних рівнянь, періодичні розв'язки. 